\title{
Rygte og atlas
}

\section{- $i$ anledning af topografien som genre}

\section{MARIANNE Ping HUANG}

so (as in a mirror) will set before your eyes, the whole world, that in the making use of some rudiments, ye may finde out the causes of things, and so by attayning unto wisdom and prudence, by this meanes leade the Reader to higher speculation Mercator: Atlas sive cosmograficae mediationes de fabrica mundi et fabricati figura

prosaens anatomi er ligesom ganens upersonlige riller og rytmer i principiel endeles kontinuitet

Henrik Bjelke: Hundrede postkort fra helvede

Henrik Bjelke har kaldt sine fortællinger i Nattens Budapest (1989) og Rygternes atlas (1991) topografier. Topografien er en lille, stedsbeskrivende genre - $\mathrm{i}$ både litteratur og malerkunst. Den er også en kartografisk genre, kortlægning af et landskab eller en by, i lighed med geografien og korografien, kortlægningen af verden og af det enkelte landområde. Således er det ikke tilfældigt, at atlasset som kartografiens bog par excellence indgår i titlen på Bjelkes anden samling. Atlasset er også hos Bjelke en samling af kort, ikke over steder, men netop over rygter, over små, uhæftede eller endda uvederhæftige historier, forbindelser og detaljer.

Bjelkes genre-benævnelse skal ikke læses som et direkte stedsbeskrivende anliggende - selv om der berettes om steder, fra 
Budapest til Dublin, fra Aix til Nepal og Madagascar. Det topografiske sted hos Bjelke er imidlertid ikke disse lande, områder eller byer; topografierne handler ikke om stederne, men i stedet om genklange i forestillinger, anekdoter og rygter, som bl.a. stedet afsætter. Topografiens sted er altså narrativt.

Sådan kan man sammenligne Bjelkes fortællinger med f.eks. Peter Esterházys 'beskrivelse' af Europas centralrum og -åre i Ned ad Donau eller Grevinde Hahn-Hahns blik eller med Claudio Magris' måske mere kendte skildring af det samme, Donau, hvor et geografisk rum og dets mytiske konturer opløses i narrativ slentren og således alligevel fortælles kartografisk eller rettere i en kortlægning af forholdet mellem fortællingers rum og fortællingers territorier. Stederne berettes, løseligt og digressivt, snarere end de beskrives og fastholdes - som det bemærkes hos Peter Esterházy om kortlægningen af den europæiske grænse mellem øst og vest, som er intetsteds og overalt:

„Siger den unge herre, at han rejser mod øst? Hele tiden mod øst? Men hvis han ikke standser op, hvor kommer han så hen? Nå? Nå? Til vest! Det mest vestlige vest. Det er nu en stor ting, at jorden er rund! Forstår De? Det er håbet. Håbet om at der ikke findes noget mest østligt,"

Jeg prøver at læse lidt. Jonathan Harper (Bram Stoker: Grev Draculas udvalgte misgerninger) bestyrker mig $i$, at Østen begynder her. Jeg undersøger mine medpassagerers hjørnetænder. ${ }^{1}$

Henrik Bjelkes topografier er rum for sådan en løselig og løsagtig kartografi og narration - topografierne er fortællinger spundet i rygternes, anekdoternes og citaternes svævende former. Bjelkes kortprosa-form minder mere om the yarn end om f.eks. novellen, og deri ligger en bevidst (og for Bjelke karakteristisk) modstand mod territorialisering. Det interessante ved topografierne er, at de undviger fortællingens territorialitet, men opretholder et narrativt rum. The yarn, fortællingen hvor der spindes en ende, berettes fra grænsen til narrativ linearitet - det ligger i dette at spinde en ende, som genfindes i den engelske term, der også betyder garn: 
Som en kompliceret anekdote eller en serie af anekdoter fortælles the yarn i dagligsprog og en henkastet tone, der er kongenial med en fortæller, som hører til $\mathrm{i}$ en oral tradition. Betegnelsen har sin rod i søfartssprog, hvor det at splejse tovværk blev en metafor for at spinde en ende. ${ }^{2}$

Splejsningen samler de strittende ender, den tilvejebringer altså en linje i det uhæftede eller uvederhæftige. Linjen er imidlertid mindre forbundet med den narrative series indre sammenhæng end med fortællerens ligefremhed, hvad angår det urimeliges selvfølgeligheder. Heri får the yarn både kontur og bundløshed: Usandsynlige småhistorier og indfald berettes i en 'realistisk' tone, der intet har at skaffe med fortællingens sandhed, men begrundes $i$, at the yarn er sin egen anledning. Den er i sin enkleste form uden eksemplets karakter, uden repræsentativ værdi. Hvilket videre har sin årsag $i$, at den fortælles i en afladt ramme, typisk under venten - i et ophold på tidens fremadhastende linje. The yarn er en fortælling uden for territoriet, og sådan fortæller Marlow i Joseph Conrads Heart of Darkness på dækket af den lille yacht, Nellie, mens selskabet venter på tidevandets skiften:

Vi så til og ventede tålmodigt - der var ikke andet at gøre, før højvandet var til ende; men det var først efter en lang tavshed, da han sagde, med tøvende stemme: "Jeg anta'r I gutter husker, at jeg engang blev ferskvands sømand en tid" at vi vidste at nu, før ebben begyndte at løbe, var vi forudbestemt [fated] til at høre om en af Marlows resultatløse oplevelser [inconclusive experiences]. ${ }^{3}$

At Henrik Bjelke i sine topografier sammenknytter en række detailfortællinger, rygter og anekdoter, som i al fald ikke alle har nødvendighed for narrationens gennemførelse, gør dem anderledes lette (og matter-of-fact) end Bjelkes (forudgående) romaner. Affektive og paranoiske undvigemanøvrer over for sproglig territorialisering, f.eks. meningsopløsende bevægelser fra ord til lyd, finder man også i topografierne, men reflekteret gennem narrative konturer og mønstrer, som distancerer det rent deliriske gennem en raffineret bevidsthed om de små genrer i oralitetens upersonlige omløb. 
Topografien figureres anekdotisk omkring en skandale, en grænseerfaring og dens sproglighed, som Henrik Bjelke i essayet "Skandalens sted" (i samlingen af samme navn) forstår således:

Det, der er det anarkistiske hist og her i min tidligere produktion ved min brug af sproget, er så, at jeg visse steder bruger det, ikke til det, som den dominerende side af hjernen havde tænkt sig, det skulle bruges til; jeg bruger det til at smugle nogle landflygtige sætninger fra den ikke dominerende hjerne op i den dominerende hjerne. Forklædt som sprog. Forklædt som fortælling. Forklædt som - i det hele taget vældig forklædt. ${ }^{4}$

Det skandaløse omsættes i topografierne sjældnere inde fra sproget, men formidles eller kolporteres i f.eks. anekdotens forkortning, med distraktion og i fravær af fortællersubjektets affekt, og således til forskel fra andre dele af forfatterskabet forklædt i upersonlighed. Skandalen er i topografierne en refleksionsform distribueret i mundtlighedens små-genrer - et felt af relationelle forbindelser snarere end det ene punkt, hvor alt går under og genfordeles. Man kunne således tale om topografien som en conte philosophique et arabesque, hvor et allerede talte sprogs detaljer og smågenrer cirkulerer i en arabesk linjeføring. Måske er det endda muligt gennem det arabeske at bestemme det kartografiske princip som kortlægningens fiksér-princip mellem kontur, linjeføring og detalje; in casu Bjelkes narrative konturtegning i en løsagtig mængde af ender - digressioner, rygtedannelser, noter og lokale myter:

Under arabeskens lineatur, som $i$ et vist omfang endnu tilhører det læseliges orden, hersker der således en virtualitet af figurale kombinationsmuligheder, det ulæselige der understøtter det læselige. Man kunne måske tale om, at der her arbejder en virtuel form-figur $\mathrm{i}$ arabesken, sådan som Jean-François Lyotard har beskrevet denne, og som i een læsning viser den gode forms klare og apollinske kontur og $i$ en anden, hvor "den lineære invariant, går over i en boblen, hvor energien cirkulerer i en høj hastighed", viser os den "dårlige form", et ",bakkisk delirium ${ }^{\prime \prime} .5$ 


\section{Atlas}

I 1595 udkommer Gerhardus Mercators Atlas, det første kartografiske samle-værk over verden og dens enkeltområder. Mercators værk er barokt, i en horror vacui er det fyldt af rimelige og urimelige detaljer og ikke overraskende tilstræbes en symbolsk sammenhæng mellem cosmografica, geografica og chorografica såvel verdenskortet som den kartografiske beskrivelse af enkeltområdet i korografien spejler mikrokosmisk det universelle.

Den symbolske spejling er forudgiven, dels gennem atlassets kosmogoniske princip, dels gennem dets kartografiske system, således at det endnu ukendte, f.eks. Australia Incognita, finder sin rette plads i den geografiske orden. Verden in toto fremstilles på atlassets store kort, Nova totius orbis geografica, hvor vi ser både den kendte og endnu ukendte, men altså kartografisk identificerbare, verden fremstillet i to halvdele omkring klodens længdeakse. I "Allegories of the Atlas"6 bemærker José Rabasa:

Verdenskortet organiserer forskellige semiotiske systemer for at frembringe et spil mellem spejle, der sluttelig vil føre læseren til kontemplation af verdens Skabelse og dens Guddommelige princip: det eneste som er fraværende på Verdenskortet. [...] Vi må forstå kortet og Atlas i almindelighed på en gang som fremstillingen af en given informationsmængde (til en kollektivt hukommelse) og som en institutionering af et værktøj til at scramble forudgående territorialisering. Hukommelse og systematisk glemsel, fantastiske allegorier og geometrisk fornuft sameksisterer i Atlas med indlysende disparitet. [...]

Eftersom verden aldrig kan begribes i sin helhed gennem en kartografisk objektivisering, har et kort kun betydning inden for en subjektiv redistribuering af dets fragmenter.

Mercators verdenskort er objektivt, fordi det transformerer sin universaliserende beskrivelse af verden gennem kartografiske principper - det er netop ikke et billede, men et kort. Atlasset er i sin helhed ikke bare et verdenskort suppleret af en samling kort over enkeltområder, men udgør et system af konturer og detailniveauer, som binder totalitet og udsnit sammen på en ganske bestemt måde, hvor konturen og detaljernes delirium er betingende for hinanden. 
Verdenskortet og enkeltbeskrivelserne opnår således deres objektivitet gennem en balance mellem et guddommeligt allestedsværende, og derfor fraværende, blik og en forskruethed eller monstrøsitet, som holder kortets simultanitet af semiotiske systemer og dets detailrigdom åben for korrektion. Hvor nemlig konturerne af Australia Incognita så at sige emaneres af den kartografiske systematik, udgøres den australske korografi, kontinentets interne beskrivelse, af monstrøse og mytiske detaljer og karakteristika.

I Mercators Atlas er der ingen hvide pletter - rummet inden for korografiernes konturer er mere end fyldt af narrative ansatser og systemer. Udskillelsen af den kendte verden over for den ukendte er også udskillelsen af forskellige narrative strategier både $\mathrm{i}$ organiseringen og læsningen af kortets detailniveauer. Mens den europæiske korografi fortælles f.eks. gennem stednavnenes historik, altså i en genealogisk linearitet, fortælles de uudforskede områder gennem linjeføringer, forestillinger og drømme-spor - det er et rum for poetisk kortlægning. Der er altså i Mercators Atlas tale om to forskellige fortælle-former: territoriets og rummets.

Atlas' universelle orden og interagerende detailniveauer modarbejder ikke hinanden. Det interessante er ikke blot at forholdet mellem rum og territorium findes indskrevet i korografierne over henholdsvis den kendte og den ukendte verden, altså som en systematik i Atlas' kompilation, men at det også fungerer inde på Mercators Verdenskort, altså i Atlas' centraltekst, og at det problemløst inden for kartografiens egne objektive meridianer og projektioner - også fungerer i kortlægningen af den kendte verden. Konturen omkring det ukendte, om Australia Incognita, er ikke en eksklusiv grænse mod poetisk betydningsdannelse. Selvom monsterformer og -kategorier (som i middelalderens monstrarier) henlægges til en slags finis terrae, indskrives det monstrøse som en løsagtig strukturering af detaljernes overflod overalt i Mercators værk (og vel tydeligst i det kendte, hvis specificitet er større og detailniveau derfor rigere) og betinger Atlas' objektivitet. Det kartografiske totalperspektiv i Verdenskortet betinger og betinges af åbenheden imellem kortets detaljer, som 
både er en åbenhed for verificerende korrektion og for alternative linjeføringer. Linjeføringen, som detaljerne i geografien, korografien - og topografien - evokerer, er i sagens interesse, nemlig Mercators tilnærmelse til det eksakte og præcise som bekræftelse af skaberværket, et i det uendelige, synkront og diakront, korrigerbare felt.

At læse Mercators verdenskort er derfor at foretage en "subjektiv redistribuering ", det vil sige at agere i det, José Rabasa kalder Mercators palimpsest eller bricolage, men uden at læsningens linjeføringer opløser konstruktionens konturer: „prosaens anatomi er ligesom ganens upersonlige riller og rytmer i principiel endeløs kontinuitet". Det betingede forhold hos Mercator mellem kontur og åbenhed, mellem territorium og rum er kartografiens arabeskes potentiale, som kan genfindes i Henrik Bjelkes topografier. Titler på de enkelte fortællinger udpeger formen som sammenkog, linjeføring og ideosynkratisk detaljering: „Irsk Stuvning“, ,Arabesque“, ,"Kong Faruks lommeur".

\section{Ad omveje i beskrivelse af det enkelte}

Topografien er hos Bjelke en narrativ genre - der henvises i begge samlinger til topografien som en særskilt, regelbunden fremstilling. Bjelke udpeger altså en æstetisk og narrativ kontur for sit skandale-arbejde:

Topografi: gr. (topos, Sted; grafein, skrive), Stedsskildring, Beskrivelse i det enkelte over Steder el. Egne, ogs. over et Distrikt el. helt Land.

Men konturen afgrænser ikke et territorium, selvom bagsideteksten er snu og helst vil være for- eller præ-tekst. Genrehenvisningens lakoniske pedanteri fører snart på af- og ad omveje, for samlingernes frontespiece er mindre lakonisk: 'Nattens Budapest', 'Rygternes atlas' - sammenskrivningens genitiv hverken specificerer eller klassificerer, som den burde. Titlens genitiv forstyrrer læsningens retningssans: Hvilket atlas? Hvordan kortlægges rygter?

Mistroen til titlernes semantiske retning fører fra den ellers tillidsvækkende leksikalitet i 'topografi', etymologisk bestemt som 
både 'sted' og 'skriven', på afveje, som også går gennem den fordoblede betydning af 'topos': 'Sted' og retorisk topik, anvendelsen af alment anerkendte synspunkter i argumentationens inventio; ikke mindst Curtius' bestemmelse, "'feste Clichés oder Denk- und Ausdrucksschemata'", peger på det allerede talte, som hos Bjelke er afsæt for sprogdelirium og anekdotisk forkortning. Pedantisk forfølger jeg omvejen i det supplerende opslag7: "vorgeprägte Formeln, Phrasen, Wendungen, Zitate, stereotype Bilder, Embleme, tradierte Motive [...]". Altså Bjelkes både abjektive og euforiske begreb om versatil trafiks: at sprogbrugen - også den poetiske - ligger på tungen og vokser i mundhulen efter allerede at have været $i$ en andens mund.

Frontespiecens afstikker fra genrebestemmelsens pedanteri peger ind $\mathrm{i}$ et mellemrum, altså på det skandaløse sted for Bjelkes sprogdelirier, men også på kronotopien i the yarn: Mellem tungen og "ganens upersonlige riller og rytmer" ordnes rygterne, lydene, ordene $\mathrm{i}$ indbyrdes bestemte funktioner og malfunktioner.

Som en genre i billedkunsten er topografi en fremstilling af et landskab eller en by, som tilstræber orientering snarere end symbolsk sammenhæng. Sådan forstår i al fald Stephan Oettermann genren..$^{9}$ Det topografiske billede finder sin form i det 17. århundredes landskabsstik, som ved første blik forekommer 'realistisk'. Topografien ligner et landskabsmaleri, men er et kort:

De er i højere grad beslægtet med et landkort end med en realistisk gengivelse af et landskab, fordi der fremfor alt arbejdes med optiske forkortelser. I deres totalitet lader de os ganske vist nøjagtig genkende den afbillede by, men kun igennem en overdimensionering og tydeliggørelse af markante punkter; de snarere karikerer end portrætterer det fremstillede sted.

Topografien er altså ikke alene en „Beskrivelse i det enkelte”, men en beskrivelse som kun gennem hyperbolens forvrængning af det enkelte kan fremstille en genkendelig helhed for blikket. Der er tale om en selektion, men især om en radikal formgivning 
og overeksponering af det selekterede - for at sikre orienteringslinjerne mellem pejlepunkterne.

Når man kan tale om, at sprogrummet i Bjelkes topografier får retning, sker det med udgangspunkt i sådanne overdimensioneringer og bogstaveliggørelser af det punktuelt skandaløse: inklusionen af det modsatrettede, inversionen i det homoerotiske, ekstasen i et oralt begær efter sprog og abjektionen ved sprogets obskøne cirkulation - emblematisk for sidstnævnte er tungen og mundhulen. Eufori og afsky i den forbindelse angår tilegnelse af, men også grænsesætning i og omkring sproget. Bjelkes orale strategi består i at omsætte kendt til ukendt ved at indoptage sproget og omdanne det allerede taltes territorialitet til rum, helt i overensstemmelse med det ovenfor citerede fra "Skandalens sted“. Sådan konfigurerer topografierne en kartografi over sprogbrugens territorier og rygte-rum. Forholdet til den andens sprog som et forhold mellem sprogrum og sprogterritorium fremstiller Julia Kristeva ${ }^{10}$ som en vej til udsigelse - en fremstilling, hvori Bjelkes pastiche-strategi,11 der både er indgåen i den versatile trafik og undvigemanøvre inden for den, lejrer sig:

[...] lysten ved at tygge, sluge, og ernære sig... af ord. Ved at være i stand til at modtage den andens ord, at indoptage, gentage og reproducere dem, bliver jeg som ham: En. Et subjekt for udsigelse.

\section{Dago dome ba grubbel ma be}

Vi er ved slutningen af topografien „Vilhelm Callesøes testamente“ (Nattens Budapest, pp. 57): „Dago dome ba grubbel ma be": remsen har rytme, den er ordløs, men ikke uden deliriske valeurer, når den løber over tungen og under ganens riller. Remsen er imidlertid også et chiffer, omtalte Callesøes testamente:

Ordene svømmede rundt $\mathrm{i}$ vore hoveder. Kalde-sø. "Dago dome ba grubbel ma be", sagde havet. "They control me by crippling my speech", sagde vinden. 
Det er særegent for Bjelkes topografiske form, at der etableres et myselium af historier, som forbinder remsens nonsense med dechifreringens distræte rationale - her den testamentariske advarsel. Topografien om sproglærer og cigar-entusiast Vilhelm Callesøe er en fortælling om sproglig rummelighed og sproglig afskæring. Den er også en let modvillig kriminalfortælling om mordet på Callesøe og en nazistisk konspiration mod sproget. Når jeg kalder den modvillig, er det fordi distraktionen i the yarn's splejsearbejde ikke er kongenial med afsløringens rettethed i kriminalfortællingen. Og det fortællende antrit $i$ „Vilhelm Callesøes testamente" er løst, fra åbningen i Ugeskrift for læger med Doktor Keplovskys artikel om "munden som hallocinogen besættelse", over et venskabeligt væddemål mellem fortælleren og Callesøes nevø, Svend, igennem en versatil trafik af overleverede beretninger, anekdoter og almindelig rygtekolportering hvori de forfærdende resultater af cigarrygning og tungekys afsløres, til den i lighed med åbningen afladte slutningen, vindens dechifrering af remsens chiffer-streng.

Vilhelm Callesøe rejste i sin ungdom til Madagascar, en $\varnothing$, hvis geografiske historie tenderer det skandaløse, hvis realforekomster nærmer sig det monstrøse, og som implicit er en refleksion af den kartografisk billedliggjorte genre, øen efter længere tids opankring ved Afrikas kyst pludselig finder sig placeret i:

Madagascar, en $\varnothing$ der jo [...] aldrig havde hængt sammen med det afrikanske kontinent eller med noget kontinent overhovedet men selv i Pangæa-perioden for 225 millioner år siden havde ligget kilet ind mellem Afrikapladen og en trekantet plade, der senere gled op og sluttede sig til Eurasienpladen og nu hedder Indien, af hvilken grund øen altid havde haft en flora og fauna ganske forskellig fra klodens øvrige kontinenter (jordbær i melonformat).

På Madagascar udvikler Callesøe en fremmedsprogspædagogik, "foreign tongue adaption", som han efter tunge trængsler og tilbage i det danske praktiserer i sin sprogundervisning af flygtninge. Callesøe fostrede på Madagascar foruden sproget endnu to lidenskaber, den ene for en madagassiske skønhed, Andriambololona Raoélina, i daglig tale Driana, den anden for en 
madagassisk sukkerørscigar, af mærket Raha Tsi Rano Tsi Afo (,ikke vand, ikke ild“), som nydt uden for øen er den rene gift. De tre lidenskaber bliver Callesøes skæbne. Han myrdes med et livslangt forbrug af cigarer af omtalte Doktor Keplovsky, som før Vilhelm var Drianas elsker og som især dølger en fortid som nazist og således bringes i Blut- und Boden-affekt over Callesøes engagement i sprogets i alle henseender uordentlige og grænseløse versalitet.

"Vilhelm Callesøes testamente" er topografisk i en række af de ovenfor skitserede henseender. Fortællingen har naturligvis en eksplicit narrativ kontur i historien om den bizarre forbrydelse, som imidlertid også er en (ligeledes konturfast) allegori over sprogets rum(melighed) over for dets territorialisering. Emblematisk herfor er overdimensioneringen og bogstaveliggørelsen af sprogets resonans og rytme i historier om og puns over tungen, mundhulen, talen og tavsheden. Disse topografiske pejlepunkter for fortællingens anliggende cirkuleres i anekdotiske bizarrerier - som da Callesøe tror at have bidt Drianas tunge af for derefter at stille sin sult med denne bogstaveliggjorte versatile trafik eller i surreelle eksempeltekster om tungen og mundhulen som delirisk og angstprovokerende hallucinogen:

I bassinet hans enorme tunge, aldrig i hvile, skælvende. Foroven ganen gråligt belagt. Langt borte svælget med dets lurende opstød. Langs kindtænderne rækker af skyskrabere uens og plomberede, for store for mundhulen. I små gemte lommer pludselig stille fugt, slubrende, med lyskrystaller i, og højt under ganespalten fuglenes åndsvage ornamentik i evig glideflugt.

Med en urimelig, men matter-of-fact konsekvens pejles disse emblemer overalt i fortællingens mangeartede småhistorier - ikke alene i Callesøes overleverede dagbøger og i anekdoter om han, men også i fortællerens digressive refleksioner og sidefortællinger. Historiens karakter af yarn figureres om de emblematiske pejlepunkter. „Vilhelm Callesøes testamente" er ikke helt sin egen anledning, men topografiens ydre anliggende, prosaens uendelige kontinuitet på randen af en delirisk opløsning i det 
remsende - garnet, som ligger under the yarn - lader sig kun vise ved at spinde ender om dens emblematik, som „fuglenes åndssvage ornamentik i evig glideflugt".

Forholdet mellem sprogterritorium og sprogrum fremsættes fra begyndelsen af „Vilhelm Callesøes testamente” som en modstilling mellem Keplovskys bestemmelse af den skandaløse tekst som „poetisk afsløring af noget patologisk” og jeg-fortællerens anderledes læsning, „noget jeg som publikummer ville kalde en poetisk erfaring." Keplovskys politiske vision er en totalbeherskelse af sproget gennem tavshed, som effektueres ved at der allerede i skolealderen lægges et diminutivt snit i tungen, som for altid afskærer talen: Sproget total-konfiguration som territorium og hvidhed, hvis modsætning er topografiens egen betingethed af et forhold mellem kontur og detaljering. „Vilhelm Callesøes testamente" drejer sig altså både om beherskelsen af sproget på andres og verdens vegne og om den poetiske betydningsdannelses obskønitet og monstrøsitet, på færde overalt, hvor sproget løber over eller fra mund til mund.

\section{Mundens engel}

Bjelkes topografier er en kortlægning af begæret efter at tage ordet i sin mund uden at tage det ud af den andens. Topografien bliver da også det at skrive i topoi, den specifikt litterære udgave af en versatil trafik. Den yarn, som der er talt meget om, er derfor i sagens natur ingen primær form i Bjelkes fortællinger, men er sekundær, en pastiche.

Yarnens linjeføring indfrier, som narrativ undvigelse af fortællingens territorialisering og opretholdelse af et fortællerum, topografiens orden. Der er en retning hos Bjelke mod sprogets forsvindingspunkter, mod at spytte ordet ud for at sutte videre på dets lyd, som kun holdes i skak af objektiveringen af fortællingen i dens interne små-genrer. Oraliteten udfoldes netop i de små genrers upersonlige felt - hvem har nogensinde truffet forfatteren til et rygte - og ikke som i den primære oralitet, hvor traditionen overpersonligt udfolder mellem fortæller og tilhørere som en bekræftelse af fællesskabets udspring og rum i en Grün- 
dermyte, hvis fornemmeste kvalitet er at stadfæste grænsen for et territorium. Bjelkes oralitet er sekundær i sin mundtliggørelse af skriften: det stof, der cirkuleres i hans contes philosophiques et arabesques, er tænkningens paradokser og hidrører fra en afgrænset skriftkultur, mens cirkulationens narrative former mimer mundtlighed.

Mimningen af det orale - den lille forskydning i forhold til rygtets, anekdotens og 'skrønens' mundtlige enkelhed - er et modernitetsmærke i oraliteten. The yarn er hos Conrad og Bjelke som hos Esterházy pastiche, på en gang selvfølgelig, urimelig og reflekteret. Joseph Conrads Marlow er ikke sømand i almindelig forstand, fordi han ikke inkarnerer det territoriale krav som var ballast i imperiets flåde, men som "a wanderer" inkarnerer rummet som en grænse i territoriet. Derfor beretter han i en narrativ linjeføring, der både ligner og er forskellig fra the yarn's primære oralitet:

Sømænds historier har en direkte enkelhed, hvis hele betydning ligger inde i skallen, i en knækket nød. Men Marlow var ikke typisk (hvis man undtager hans hang til at spinde en ende), og for ham lå en episodes betydning ikke indeni som en kærne, men udenfor, og omspændte den historie som bragte den frem, men kun sådan som en glød bringer en varmedis frem, så den antager lighed med disse tågedeglorier, der nogle gange synliggøres af måneskærs spøgelsesagtige lysen. 12

Hos Henrik Bjelkes har mundtligheden et lignede, på en gang reflektorisk og løsagtigt niveau, som afviser anliggendet på vegne af skandalen - som Karl Kraus læst af Walter Benjamin ${ }^{13}$ er Bjelke i sine topografier sprogets kannibaliserende Unmensch, mundhulens engel:

Som Atlas, der bar verden på sine skuldre, bærer enhver verden, ikke på skuldrene men i munden, for det er der, vi lever og vor artikulation af verden er verden. Tag den verden, som Atlas bærer væk, og der er ingen Atlas, for så kendte vi ham ikke. 


\section{Noter:}

1. Peter Esterházy: Ned ad Donau. Dansk oversættelse, 1994, p. 202.

2. Ian Reid: The Short Story, p. 33.

3. Der citeres fra Jørgen Sonnes oversættelse, 2. udgave, Kbh. 1989, p. 11.

4. Skandalens sted, Kbh. 1992, p. 226.

5. Carsten Madsen: „Arabeskens Idé og lineatur”, Passage 16, p. 63.

6. Refleksionerne over Mercators Atlas er baseret på José Rabasas artikel "Allegories of the Atlas" (in: Europe and Its Others, ed. Francis Barker et al. Colchester, Univ. of Essex, 1985). Citatet (p.3) er i min oversættelse. 7. Topos in Gero von Wilpert: Sachwörterbuch der Literatur, Stuttgart 1989.

8. Se Per Stounbjergs artikel „Noget om beskaffenheden af Bjelkes romaner" andetsteds i tidsskriftet.

9. Stephan Oettermann: Das Panorama: Die Geschichte eines Massenmediums. Frankfurt a.M. 1980. Citatet (p. 22) er i min oversættelse.

10. Julia Kristeva: Tales of Love, N.Y., Columbia Univ. Press 1987. Citatet (p. 26) er i min oversættelse.

11. Jvf. Niels Egebaki „Pastichen som kunstnerisk princip”. In Afen evighedsstudents meriter, Århus 1991.

12. Der citeres fra Jørgen Sonnes oversættelse, p. 8.

13. Jvf. Walter Benjamin: „Karl Kraus”, Gesammelte Schriften, Bd. II.1, Frankfurt a. M. 1977, p. 367: „Ikke renhed og ikke offer blev dæmonens herre; men hvor oprindelse [Ursprung] og ødelæggelse finder hinanden er dæmonens herredømme forbi. Som en skabning af barn og menneskeæder står dens overvinder foran den: ikke et nyt menneske; et umenneske; en ny engel." (Min oversættelse). 